\title{
Refugees and the Future World: Fuelling conflict of Ethnicities?
}

\author{
Md. Rajin Makhdum Khan \\ Bangladesh University of Professionals \\ rajin_drmc@yahoo.com \\ Faizah Imam \\ Bangladesh University of Professionals \\ faizah_imam.89@gmail.com
}

\begin{abstract}
This dissertation focuses on identifying the nature of the future world in respect to the advent of extended number of refugees. Refugee migration and crisis in outside the original countries owing to a deluge of refugees is an important phenomenon happening throughout the world currently. With the case study analysis of current refugee migration events in Asia, Middle East, Africa and the Americas, the paper tries to find out the future nature of the smallest unit of analysis for a long time - nation state. All features of economic, religious, ethnic and cultural aspects taking into account, the core argument centers around whether the influx of refugees into outer or neighbor countries is increasing the possibility of ethnic conflict throughout the world making the future world a world full of feuds and conflicts. The dissertation also tries to find out the true aspects of Samuel Huntington's Clash of Civilizations theory and if the theory is going to be signified in a future world full of feuds and conflicts. With historical and contemporary analysis of the various cases of refugee influx, the paper also tries to measure the economic consequences of refugee migration and influx. Do globalization and liberal economies tend to survive or does the refugee influx prevent cooperation among ethnicities and states? The dissertation also attempts to find out whether refugee crisis would instigate ethnic nationalism and if the neoliberal world order would fall apart owing to the problems originated by huge refugee influx and migration. KEY WORDS: Refugees, Influx, Ethnicity, Migration, Conflict, Nations, Clash.
\end{abstract}




\section{Introduction}

As we stand in the twenty-first century, the world remains apathetic to its ongoing events and 'civil war' has become a destiny of the world. Sectarian conflicts, ideological movements and revolution in warfare - all these things have made the world's happenings much more complicated. While the post World War II world order aimed at preserving peace, the world is quite on the path to turn itself into another battlefield in Africa. Africa is more like the new Europe with its huge number of ongoing clashes with very similar characteristics like the pre WWII Europe. The decolonized states of Asia, South America and Central America does not exempt from having this clashes. Although these three continental countries do not have the events of war and heavy battles, persecution on the basis of religion or ideology has been a continual feature of these regions. John Berger has previously pointed out that 'the twentieth century' had been 'the century of departure, migration, exodus and disappearance (Gatrell 2013,1). As things are going on, the early twenty-first century is not walking on a much different path than its predecessor. The twentyfirst century's beginning has been encircled with the influx of refugees. As Peter Gatrell points out, by the end of 2012, there has been an existence of nine million refugees in refugee settlements (Gatrell 2013,1).

The forced migration of persecuted people in Iraq, Afghanistan, Syria, Horn of Africa and the Great Lakes Region is a solid example that this century is not very different from its predecessor one in the aspect of refugee influx (Gatrell 2013, 1). Refugees had been, are and will be a constant reality of our living world. As globalization and intercommunication alongside interconnectedness increases by time, refugees and forced migration also seemingly increase. This constant reality throttles the harmonious society in many aspects. The argument therefore needs to cover the constructed social and psychological aspects and the stubborn persecution by the majorities or the rulers.

\section{Who Are the Refugees?}

The 1951 United Nations Convention relating to the Status of Refugees defines a refugee as a person "who is outside the country of his nationality, owing to a well-founded fear of being persecuted for reasons of race, religion, nationality and membership of a particular social group or political opinion' (Koser 2007,71). However, this definition is criticized because it does not cover the aspects of environmental refugees who have 
fled their country of origin owing to the force of climate change and other natural disasters (Koser 2007, 71). The other criticism of this definition is that it does not count women or gender as a specific or different categorization of group or subject of forced migration (Koser 2007, 71).

Before the advent of the Refugee convention, a severe scarcity and difference in the perception of refugees seemed to occur. For instance, the Russians were willing to identify the people who were forced to leave their place of origin due to the decision of administrative resettlement or war strategy as forced migrants where the spontaneously leaving place of origin was counted as refugeedom (Gatrell 2013,30). Another example is found in the interpretation of the Austro-Hungarians (Gatrell 2013,30). They preferred the term 'evacuees' for the people who were forced to migrate where 'refugee' was the term for people who willingly migrated to some other place rather than being forced.

In order to eradicate all these confusions, the refugee convention in 1951 was proclaimed. As it has grown old now, according to some scholars, this convention needs a revision for new amendments. According to Khalid Koser, one argument against this convention is that it needs amendment concerning the emergence of new type of events (Koser 2007, 71). Despite all these debate, arguments and criticism, the definition above is an indispensable one owing to its global application.

\section{Constructivism: The Conflict of Perceptions}

Constructivism is also perceived as social constructivism. As we will discuss further, it is to be learned that constructivism merely depends on the structure of the society, social norms and social regulations that have been previously set up in the society and therefore influences the individual in many ways. Constructivists emphasize on normative and ideational structures as the instruments of shaping the social identities of political and individual actors (Reus-Smit 2001,217).

Social Constructivism or, Constructivism, predominantly sheds a spotlight on the interaction and interrelationship between structure and agency through the regulation and occurrence of norms, ideas and interests (Steans et al. 2010, 183). The themes that are explained by the constructivist theoretical framework include the construction of national interests, human rights stretching, and international organizations' role on state identities (Steans et al. 2010, 183). Constructivism in these explanations therefore do not interpret voluntary acts rather it proposes a social process run by the 
structural framework on a person bereft of a single person or individual's influence than a collective effort (Steans et al. 2010, 183).

The constructivist agenda implies the role of constructed knowledge on the policy making of a country or a society (Steans et al.2010,191). This is where the event of the refugee influx and its impact takes place. As the refugees are persons who were forced to flee from their motherland or place of origin with a well-founded fear and panic of being persecuted, according to constructivism, this fright is to haunt them forever. Even when they land at a new land where the norms and regulations are different than what they had experienced before and what they want from their constructed idea, they are caught in a dilemma again. The dilemma is a two-way traffic in this case. Their place of origin persecutes them for being a minority or because of belonging to a particular group where they are alienated by their distinct cultural fruition and practice. Their new shelter also denies them with a fear of alien ideas and norms that they might inflict into the new area.

This idea is explained by Slavoj Zizek as the Europeans perceive the Middle Eastern and African refugees as a threat to their peaceful life owing to a constructed idea that these refugees are radical Islamists who might infect serious harm to their lives and the society (Žižek 2016,1). They are caught in a double blackmail situation as said by him. They are being maltreated and hounded by a counter ideological force because of the difference in ideas and in the new shelter they are again faced with the similar problem. Constructivism extensively focuses on subjectivity and thus explains the conflict of perceptions and ideas. Identity is the key factor in the making of policies. Identity is a solid characteristic that cannot be easily altered (Steans et al. 2010, 197). Constructivism also identifies another problem of this refugee influx's future. The persecution and forced fleeing makes the refugees experience brutal and despondent events that makes them individually dejected forever. The brutality affects their ideas and their perception of the world which makes them violent in the future and this can be attributed to the radical Islamist attacks by the Muslim refugees or the migrants. Suppose a Syrian refugee who takes refuge in Vienna might feel an antagonistic feeling in future to the culture and norms of Vienna which are fundamentally very different than that of Syria. When he perceives this as a threat, the brutality endured by him might sway him to commit a violent attack on Christian Vienna citizens as his constructed idea of the misery he endured pursues him to do. In this case, we will eventually see whether the two-way traffic of fear for each other (permanent citizens and refugees) is evident and actually true. 


\section{The Refugees of Twenty-First Century}

Since 1945, the worldwide refugee number is counted as 21.3 million whereas the people who cannot cross the international border but are forced to be internally displaced may constitute to an amount of 65.3 million (Betts and Collier 2017, 25). UNHCR measured that about 8.4 million refugees lived in this world at the end of the year 2005 (Koser 2007, 75). The number of refugees has lessened through years from that of 17 million refugees in 1990 owing to the dramatic return of massive refugees to their home from that time being (Koser 2007, 75).

The largest contributor to the number of refugees is perhaps Afghanistan. The country had a number of 2 million refugees in 2005 mainly living in Iran and Pakistan (Koser $2007,75)$. The other countries that created a massive influx of refugees owing to their internal political turmoil and violence include Sudan, Burundi, the Democratic Republic of Congo and Somalia (Koser 2007, 75). Although Afghanistan has the shame of having the highest number of refugees, the continent mostly affected by political turmoil and persecution alongside brutal violence is Africa (Koser 2007, 75). Refugees seek their asylum mostly in the industrialized countries in Europe. The United Kingdom is an exemplary country of allowing a good number of refugees or asylum-seekers (Koser 2007, 87). About 10 to 20 percent of the people were allowed to have asylum in the UK after cavernous observations (Koser 2007,87). The United States of America has so far granted the maximum number of refugees or asylumseekers (around 54,000) where Canada (10,400) and Australia (11,700) were just behind the USA, although by a great amount of difference in the aspect of resettled refugees (Koser 2007, 75).

The protracted civil wars have contributed a lot to the massive influx of refugees. UNHCR anticipated 38 different protracted persecution or fearful situations in countries owing to political or ideological clashes and therefore causing brutal civil wars producing about 6.2 million refugees in total at the end of 2003 (Koser 2007, 79). The Bhutanese refugees in Nepal, Afghan refugees in Pakistan and Iran, Somali refugees in Kenya, Yemen, Ethiopia and Djibouti are some examples of these protractedly settled refugees (Koser 2007,79). During the civil war owing to a revolution in want of Muammar Gaddafi's removal from the throne of the country, Tunisia accepted refugees from Libya in 2011 (Gatrell 2013, 290). By the end of 2005, the number of worldwide refugees was measured as 9.2 million (Castles 2006, 13). Stephen Castles points out that "Refugees mostly come from the countries where wars, violence and human rights violations are taking place and the top ten statistically measured countries of origin of refugee population are identified as Afghanistan, 
Sudan, Burundi, Democratic Republic of Congo, Palestine, Somalia, Iraq, Vietnam, Liberia and Angola whereas the top ten host countries of refugees are Pakistan, Iran, Germany, Tanzania, the USA, China, Serbia, the UK, Saudi Arabia and Armenia." (Castles 2006, 13) The Rwandan Civil War, African World War, 20 ${ }^{\text {th }}$ Century Balkan civil wars and civil war in Chechnya have also generated a good number of refugees (Castles 2006, 19). Stephen Castles also identifies Azerbaijan as a protracted refugee situation country (Castles 2006, 20).

Persecution of Rohingyas in the Rakhine state of Myanmar has generated a huge amount of Rohingya refugee influx to Bangladesh and other countries (Southwick 2017). The official account of Rohingya refugees in Bangladesh through registered report measures the number to be over 30,000 (Kabir 2017). Although the actual number is much higher than the official one, the official account does not provide enough faith on the fact that it is a minor issue. All these violent events and the huge influx of refugees have put the future of this century to a great dubiety. This century looks more likely walking on a similar path that of the twentieth century - the century of refugeedom.

\section{Huntington's Clash of Civilizations}

Samuel P. Huntington envisaged a new world order based on civilization (Huntington $2003,20)$. The western idea of being universal was supposed to clash with the others (Huntington 2003, 20). His idea was based on a broad range of statistical measurements where the Muslim world was counted as a unified one civilization or group actor. But was his assumption really true? Muslims are fighting with each other in the Middle East. Are they really a unified single actor?

The Syrian refugees are the result of a sectarian conflict of the Muslims. Although he propounded that Muslims would have to stop fighting between themselves first and a core Islamic state (a leader in other words) would have to be established in order to counter the western civilization (Huntington 2003, 264-265). His core idea was however to the western approach and belief of being universal would further lead it towards a feud with the Islamic or Sinic civilization (Huntington 2003, 20).

This discussion would get prolonged if the whole book is to be summarized here. Rather the focal point of refugees is to be taken into account for this discussion. The constructed brutality and violent outlook on life is the core idea that the refugees are to contain within themselves. If they are enraged and angered by the existence of an opposite ideology of what they have conceived forever, it is highly likely that 
they might fear their existence threatened again. Huntington put up the discussion of immigration as being a key trigger of the fear of the western people concerning radical Islam (Huntington 2003, 202-203). Refugees might become an evidence for Huntington's argument that the Muslim civilization will confront the western civilization. The two-way traffic and the double blackmail, both are the core effects here. The brutality experienced in Syria or Libya can ultimately make a Muslim baby very much dejected about the world. This dejection only gets fueled if the western people try to prevent the Muslims from entering into their country, practicing their rituals and religious norms alongside criticizing their religion for being too much rigid. If this cannot be resolved, Huntington's prediction might see a green light in the near future and refugees might ultimately fuel various conflicts of ethnicities in different western regions.

\section{The Myth of Nation-State}

There has been nothing called a nation-state from a very long time in the world. In a modern globalized world, the idea of nation-state is as volatile and as vague as the air. It can be felt in the mind and in the heart owing to the brain's stubborn sticking to the idea but if anyone wants to physically witness whether there is a single nation-state, none can find it. The Germans have always been very proud of being Germans, but the country of Austria has been a forever loophole since the German reunifications. Austria is also a German speaking language. Then what does prevent Austria from being a part of Germany? Germany's identification as a nation-state can also be elaborated as a vague concept with the example of its national football team.

In 2010, more than half of the team consisted of children of at least one immigrant parents (Connolly 2010). Mesut Ozil, Sami Khedira, Jerome Boateng, Lukas Podolski, Miroslav Klose, Mario Gomez - all of these players are ethnically Turkish, Tunisian, Ghanaian, Polish or Spanish who were representing the national football team at that time. Germany has received more number of North African immigrants; specially Turkish and Tunisian migrants whereas France, Spain and Belgium have also received Algerian, Moroccan and Tunisian population. "The United States has always been a country of immigrants" - Samuel P. Huntington $(2003,202)$ insisted in his argument. Michael Samers and Michael Collyer's statistics of immigrants shows us that there can be no unilaterally purified nation-state in Europe (Samers and Collyer 2010, 24). All these aspects provide us with ample arguments that forced migrants newly entering the countries are not a new trouble for the countries when there has already been a huge amount of immigrants living. But the constructivist argument shows us the only 
counterargument - the violent experience and in turn - violent behavior might change the whole course of traffic and eventually turn into a devastating accident.

\section{Conclusionः A World with No Harmony?}

Nationalism is not a good spirit for an economically interdependent world order and specifically in this era of massive globalization. Nationalism can negatively create conflicts inside the state with its vague and volatile conception. Creation of enemies, glorification of the state in times of turmoil, overlapping with religion, and discrimination against minorities - all these can take place in a state owing to the spirit of nationalism (Cox 1998, 34-36). The economic consequence of refugee migration is another aspect why people want to prevent the influx of refugees. When new people come to a place, the job market of that place gets some new offering laborers. With increased number of laborers, the job market gets overloaded and threatens the job security of the people who have been living in that place for a long time. This makes the market efficient with a competition among labor-sellers but hurts people's income and earnings. There can be debate regarding this among people, but it is more than evident that without earning, a man cannot live his life. Economic aspect of life becomes more dominant when the proper scarcity is faced. The refugee migration thus provides new contests for the ethnic people living in that region through challenging them in the market.

The old number of immigrants does not make us fearful of a conflict between the migrants and the local populace and it should be realized that they have already got integrated with the locals. This argument, however, insists on giving the new refugees more time for being integrated with the locals. But the constructivist agenda aforementioned and the economic threat the refugees throw towards the local populace makes a confrontation between each makes a confrontation between each much more believable than the existence of a peaceful atmosphere. With security and economic threat in the mind, a peaceful action should not be expected from the locals although a sensible government can always find a way to make things work out.

\section{References}

Betts, Alexander, and Paul Collier. 2017. Refuge: Transforming A Broken Refuge System. London: Penguin Books.

Castles, Stephen. 2006. "Global Perspectives on Forced Migration". Asian And Pacific Migration Journal 15, no. 1: 7-28. doi:10.1177/011719680601500102. 
Connolly, Kate. "Germans Celebrate The Diversity Of Their 'Multiculti' World Cup Team". The Guardian, 2010. https://www.theguardian.com/football/2010/jun/27/ german-football-team-ethnic-diversity.

Cox, John K. 1998. "Nationalism”. In Introducing Global Issues. Boulder, Colorado: Lynne Rienner Publishers, Inc.

Gatrell, Peter. 2013. The Making of The Modern Refugee. 1st ed. Oxford: Oxford University Press.

Huntington, Samuel P. 2003. The Clash of Civilizations and the Remaking of World Order. New York: Simon \& Schuster.

Kabir, Arafat."Bangladesh should recalibrate its Rohingya policy”. East Asia Forum, 2017. http:// www.eastasiaforum.org/2017/02/21/bangladesh-should-recalibrate-its-rohingya-policy/.

Koser, Khalid. 2007. International Migration: A Very Short Introduction. Oxford: Oxford University Press.

Reus-Smit, Christian. 2001."Constructivism". In Theories of International Relations, 217. Scott Burchill, Richard Devetak, Andrew Linklater, Matthew Paterson, Christian Reus-Smit and Jacqui True, 2nd ed. Hampshire: Palgrave.

Samers, Michael, and Michael Collyer. 2010. Migration. Abingdon, Oxon: Routledge.

Southwick, Katherine. 2017." A turning point in the Rohingya crisis". East Asia Forum. http:// www.eastasiaforum.org/2017/03/15/a-turning-point-in-the-rohingya-crisis/.

Steans, Jill, Lloyd Pettiford, Thomas Diez, and Imad El-Anis. 2010. An Introduction to International Relations Theory: Perspectives And Themes. 3rd ed. Essex: Pearson Education Limited.

Žižek, Slavoj. 2016. Against the Double Blackmail: Refugees, Terror and Other Troubles with the Neighbors. Allen Lane. 